\title{
The Impact of Surplus Free Cash Flow, Corporate Governance and Firm Size on Earnings Predictability in Companies Listed in Tehran Stock Exchange
}

\author{
Samaneh Ahmadi Shadmehri ${ }^{1}$, Ehsan Khansalar ${ }^{2}$, George Giannopoulos ${ }^{2} \&$ Mahmoud Lari Dasht-Bayaz ${ }^{3}$ \\ ${ }^{1}$ Islamic Azad University, Qaenat Branch, Birjand, Iran \\ ${ }^{2}$ Kingston Business School, Kingston University, London, UK \\ ${ }^{3}$ Ferdowsi University of Mashhad, Mashhad, Iran \\ Correspondence: Ehsan Khansalar, Kingston Business School, Kingston University, London, UK. \\ E-mail:khansalarehsan@yahoo.com
}

Received: May 17, 2017

doi:10.5539/ibr.v10n11p20
Accepted: September 21,2017

Online Published: September 22, 2017

\begin{abstract}
Among the most important cases considered in financial statements by investors and other users of financial statements is earnings-related information. Given the need of the users of financial statements for the future information of companies and use of past data to predict the future, it seems that earnings forecast is among the favorite items of investors. In fact, earnings forecast by the management provides information about the future of companies. The main objective of the present study is to investigate the effect of surplus free cash flow, corporate governance and firm size on earnings predictability in companies listed in Tehran Stock Exchange. This research is an applied study and of post-event causal type. For data analysis, OLS regression method has been applied using Eviews software. The research results demonstrate that there is a statistically significant relationship between earnings predictability and surplus free cash flow and good corporate mechanisms play a positive role in the relationship between surplus free cash flow and earnings predictability. According to the results, in large companies, good corporate mechanisms enhance the relationship between surplus free cash flow and earnings predictability.
\end{abstract}

Keywords: surplus free cash flow, corporate governance, firm size and earnings predictability

\section{Introduction}

Earning is among the important information of financial statements that attracts the attention of investors and other users of financial statements. Provided information of the company including earnings-related information is based on the past events while users of financial statements need information on the company's future (Haqiqat \& Mo'tamed, 2011). One of the factors that should be considered in earnings forecast is earnings volatility. Sometimes, to avoid high earnings volatility, earnings smoothing is performed by managers. One of the incentives for earnings smoothing is the existence of volatile earnings (Badrinath et al., 1989). Since the earnings forecast is of utmost importance, managers pay careful attention to it. There are numerous resources and tools to enhance the accuracy of earnings forecast for managers, which will be more favorable if they lead to close-to-reality forecasts. Further, earnings forecast helps investors improve their decision-making process and reduce the risk of incorrect decisions. Investors are interested in estimating the future benefits of their investment so that they can judge on receiving the future dividend and also the value of their shares (Mashayekhi \& Shahrokhi, 2007). According to the research background, corporate governance mechanisms have an impact on the quality of information provided by the company, including the information on earnings forecast.

Different factors may affect earnings predictability. One of these factors is corporate governance (Ahmed \& Ismail, 2014). Generally, companies with poor corporate governance which are not under pressure financially tend to make more investment and faster consume the reserves of accumulated funds. Managers who are poorly controlled certainly prefer to use the funds for education and investment in other companies instead of domestic investment through capital expenditure and research and development. Evidence shows that investment for the company's education and capital expenditures and research and development in the companies with poor corporate governance decreases future profitability and corporate value (Izadiniya \& Resaeiyan, 2010). Based on the 
foregoing, the present study has examined the influence of surplus free cash flow, corporate governance and firm size on earnings predictability in companies listed in Tehran Stock Exchange for a 5-year period from 2010 to 2014.

\section{Theoretical Foundations}

One of the purposes of accounting and preparing financial statements is to provide useful information to facilitate decision-making. One effect of this usefulness is the ability to predict financial statement items. Accounting earnings forecast as a factor influencing economic decisions has long been interested by the users (Haqiqat \& Mo'tamed, 2011). Various factors can make an impact on earnings predictability. One of these factors is corporate governance (Ahmed \& Ismail, 2014). By definition, corporate governance includes rules and regulations, structures, processes, cultures and systems that cause to achieve the objectives of accountability, guiding transparency performance, justice and respect for the rights of stakeholders (Hassas Yeganeh \& Baghoumiyan, 2006). In other words, corporate governance explains a structure through which the goals of the company are specified, methods to achieve the goals are determined and finally, monitoring standards and mechanisms are identified. In this respect, many fundamental reforms have been carried out in companies in order to make sure that different components of corporate governance have been effectively implemented in the company (Germain et al., 2014).

Corporate governance is a system through which business companies are monitored and controlled. Indeed, corporate governance determines the distribution of rights and responsibilities among the various partners in the company, including the board of directors, shareholders and other stakeholders and specifies the rules and procedures for making decisions in corporate affairs. By doing so, structures are provided through which the company's goals are explained and the tool to achieve these objectives and monitoring the performance are also provided. In recent years, corporate governance has assumed great importance. In fact, corporate governance in business organizations has become an important factor for success and also increasing the quality of financial reporting of the company (Ebrahim \& Fattah, 2015). Although corporate governance features play different roles to ensure the success of companies, ultimately it is only the role of accountability that affects the commercial economy (Vakili-fard \& Bavandpour, 2010).

Van den Berg (2001) states that corporate governance is one of the important elements influencing different dimensions of the company. According to the studies conducted, if companies work to improve and promote the status of corporate governance, this can have a positive effect on various components of the company including performance, corporate value, earnings predictability and so on (Ahmed \& Ismail, 2014). Besides, another factor that can affect earnings predictability is free cash flow. Free cash flow is a yardstick to measure the performance of companies and shows the cash flow that the company has at its disposal after spending the necessary expenditures for the maintenance or development of assets.

Free cash flow is important in that it allows the company to search for opportunities that increase the shareholder value. Without having cash, developing new products, doing business education, paying cash dividends to shareholders and reducing debts are not possible. But sometimes, managers are placed in situations in which their decisions are not to the benefit of shareholders of the company and distort the financial reports. Indeed, earnings management occurs when managers enter their judgment in financial reporting and recording the financial reports in a way that modification of the content of financial reports misleads some shareholders in relation to the company's economic performance. Considering what has been mentioned, the main purpose in this study is to investigate the impact of free cash flow, corporate governance and firm size on earnings predictability in companies listed in Tehran Stock Exchange.

\section{Research Background and Hypothesis Development}

In their study, Aqaei and Chalaki (2009) assessed the relationship between corporate governance features and earnings management in companies listed in Tehran Stock Exchange. They came to the conclusion that a significant negative relationship exists between the components of institutional ownership and board independence with earnings management. Additionally, there is no significant relationship between CEO influence, CEO duality, board size and CEO tenure with earnings management.

Hoshi (2009) evaluated the effect of addressing future financial information in Section 3401 of Auditing Standards on the quality of earnings forecast. The results of this research indicate that implementing this section of Auditing Standards does not cause a reduction in prediction error and a change in the stock price. The literature review suggests that necessary studies on the relationship between management earnings forecast error and accruals have not been considered yet in Iran and in most of the studies performed, the relationship between prediction error and various factors has been tested. 
Setayesh et al. (2010) in a research examined the impact of corporate governance on earnings smoothing in companies listed in Tehran Stock Exchange. They concluded that the percentage of non-executive board members affects earnings smoothing, but board independence has no effect on it. Izadiniya and Resaeiyan (2010) investigated the relationship between corporate governance monitoring tools, level of cash holdings and value of 129 companies listed in Tehran Stock Exchange during the years 1999-1999. The obtained results revealed that there is a significant positive relationship between the percentage of institutional investors and level of cash holdings with firm value. But no significant relationship was observed between the percentage of non-executive board members and firm value.

Sabz Alipour et al. (2012) examined the relationship between corporate governance mechanisms and earnings forecast accuracy in 31 companies listed in Tehran Stock Exchange during the years 2005-2010. The results suggest that there is a significant positive relationship only between the percentage of non-executive board members and earnings forecast accuracy and no significant relationship exists between other corpo rate governance components and earnings forecast accuracy.

Ola et al. (2014) in a study evaluated the relationship between the elements of corporate governance and economic added value during the period 2006-2009. Their findings indicated that among the five elements of corporate governance, only the variable of the percentage of institutional investor ownership has a significant positive impact on economic added value. Moreover, the causal relationship between this variable and economic added value is confirmed based on Granger causality test.

Coles et al. (2001) assessed the relationship between corporate governance mechanisms and earnings forecast accuracy. By selecting 144 American companies, they concluded that companies employing more non-executive members in the board of directors have better forecast accuracy compared to the companies with greater number of executive members in the board. Dechow and Dichev (2002) studied the relationship between firm size and earnings volatility with earnings predictability. By examining the mechanism of the relationship between volatility and earnings predictability, they considered this relationship as the result of accounting and economic factors. The results of this research demonstrated that earnings volatility has a negative relationship with earnings predictability in the short and long terms. Further, firm size has a negative relationship with earnings predictability.

Pham et al. (2007) conducted a study entitled "Corporate governance, capital cost and performance" and investigated a large number of Australian companies during the years 1994-2003. The achieved findings showed that change in corporate governance mechanisms plays a crucial role in explaining the variations in the capital cost of companies. Also, they found that higher percentage of managerial ownership, presence of institutional owners and smaller and more independent board can reduce information asymmetry and risk. This causes the shareholders to demand a lower rate of return and consequently, capital cost of the company decreases. They revealed that corporate governance plays an important role in value creation for shareholders.

Adinehzadeh and Jaffar (2013) examined the relationship between corporate governance and free cash flow in 200 companies listed in Malaysia Stock Exchange. The results suggested that there is a significant positive relationship between the degree of audit committee independence, size and appropriateness of audit committee with the level of free cash flow.

Ahmed and Ismail (2014) studied the effect of surplus free cash flow, corporate governance and firm size on earnings predictability in Malaysia Stock Exchange. They considered the components of board independence, board size, independence of Chairman of the Board, institutional owners and managerial owners as a representative for corporate governance and tested the hypotheses using multivariate regression analysis. The results obtained from this study indicated that companies with high surplus free cash flow have less earnings predictability. Additionally, earning of the companies with high surplus cash flow had more predictability when institutional investors (owners) had more stock and Chairman of the Board was independent. Finally, this research demonstrated that the institutional and managerial role of owners in reducing the conflict of representation of free cash flow and improving earnings predictability in larger firms is very tangible and important. The results of this study indicate that investors still show the necessary prudence in expressing the amount of earning in relation to the ability of the board.

Chang et al. (2015) carried out a study entitled "Corporate governance, product market competition and capital structure" and investigated the relationship between corporate governance and capital structure. In this research, they considered product market competition as a moderator variable in the relationship between corporate governance and capital structure. Their findings showed that when a company with poor corporate governance is present in an industry with high competitiveness, it has greater incentive to maximize the wealth of its shareholders and this leads to faster adjustment of capital structure. 
In order to investigate the impact of surplus free cash flow, corporate governance and firm size on earnings predictability in companies listed in Tehran Stock Exchange and considering the theoretical foundations, the research hypotheses are as follows:

Surplus free cash flow makes a significant negative impact on earnings forecast ability.

Good corporate mechanisms (small board, ratio of proportionate outside directors, high institutional ownership and high managerial ownership) as an intermediary have a significant positive impact on the relationship between surplus free cash flow and earnings forecast.

The positive effect of governance mechanisms on the relationship between surplus free cash flow and earnings forecast is more prominent in larger companies.

\section{Research Methodology}

\subsection{Empirical Model}

To test the above hypotheses, the following operational models have been designed. To examine whether the SFCF agency problem deteriorates the predictive ability of earnings, we extend the future operating cash flows-current earnings relationship by adding SFCF to the relation. To control for firm characteristics, we include firm size, debt,

and loss in the model. To ensure that the moderating effect captures only the interactive effect of governance variables and SFCF, we also include board independence, board size, board leadership, institutional ownership, and managerial ownership in the model as control variables. This study interacts SFCF, firm characteristics, and governance variables with current earnings to test the incremental effect of the variables on the relationship between one-year-ahead operating cash flows and current earnings. Finally, a dummy year variable is included in the model to capture the fixed year effect. The following pooled cross-sectional model is used to test $\mathrm{H} 1$ :

$$
\begin{gathered}
C F O_{i t+1}=\beta_{0}+\beta_{1} E A R N+\beta_{2} E A R N * S F C F+\beta_{3-7} E A R N * C G+\beta_{8} E A R N+S I Z E+\beta_{9} E A R N * D E B T \\
+\beta_{10} E A R N * L O S S+\beta_{11} Y R+\varepsilon
\end{gathered}
$$

In model $1, \mathrm{CFO}_{\mathrm{it}+1}$ is cash flow from operations for firm $\mathrm{i}$ at year $\mathrm{t}+1$ scaled by beginning total assets. EARN is net income before extraordinary items for firm $\mathrm{i}$ at fiscal year $\mathrm{t}$, scaled by beginning total assets. SFCF is a binary variable with value of 1 if free cash flow (FCF, see Model 3) is above the sample median for the year and the growth ratio (market to book value of equity ratio, MBR) is below the sample median for the year, and 0 otherwise.

In addition, we compute a three-way interaction between current earnings, governance practices, and SFCF to examine the moderating effect of CG on the association between IJAIM 22,2 122 SFCF and earnings predictability. Apart from the current earnings-SFCF interaction, we expect the estimated coefficients on the three-way interaction variables to be significantly related to one-year-ahead operating cash flows in the predicted direction. The predicted

and significant association implies that firms with high SFCF, strong board structure (higher proportion of outside directors on the board, smaller board size, and independent chairman), and effective ownership structure (higher institutional ownership and high shareholding by executives) report predictable earnings. We use the following pooled cross-sectional model to test $\mathrm{H} 2$ :

$$
\begin{aligned}
C F O_{i t+1}= & \beta_{0}+\beta_{1} E A R N+\beta_{2} E A R N * S F C F+\beta_{3-7} E A R N * C G+\beta_{8-12} E A R N * C G * S F C F+\beta_{13} E A R N * \\
& S I Z E+\beta_{14} E A R N * D E B T+\beta_{15} E A R N * L O S S+\beta_{16} Y R+\varepsilon
\end{aligned}
$$

We measure the SFCF agency problem by using operational definitions of the FCF and growth prospects (MBR) of a firm. Firms with a high FCF but low growth opportunities are viewed as firms with a SFCF agency problem (Bukit and Iskandar, 2009; Chung et al. 2005; Rahman and Mohd-Saleh, 2008). Following the literature, Free cash flow (FCF) is calculated as follows:

$$
F C F_{i, t}=\left(I N C_{i t}-T A X_{i t}-I N T E X P_{i t}-O S D I V_{i t}-P S D I V_{i t}\right) / T A_{i t-1}
$$

In the formula of $3, I N C$ defined as Operating income of I firm in t year, TAX, Corporate income tax, INTEXP is Gross interest expense of short-term and long-term debts and OSDIV, Company's total common stock dividend.

\subsection{Variables Measurement}

Independent variable: In the present research, independent variables include surplus free cash flow, corporate 
governance and firm size. Surplus cash flow in this study is a dummy variable which will be 1 if there is surplus free cash flow in the company. Otherwise, it is equal to zero. In this research, corporate governance is measured through its components, i.e. board size, ratio of proportionate outside directors, the amount of institutional ownership and the amount of managerial ownership. Firm size in the present research is one of the independent variables and is measured through the natural logarithm of total assets.

Dependent variable: In this study, the dependent variable is earnings predictability. Lip (1990) has explained the concept of earnings predictability based on the variance of statistical distribution of earning of each company.

Following prior studies, a number of control variables are used in the regression models to control for potential influences between variables (Aldhamari and Ismail, 2013). The variables used include firm size, debt ratio and loss. The definitions of variables and their expected signs are summarized in Table 1.

Table 1. Definition of Variables

\begin{tabular}{cc}
\hline Variables & Definition \\
\hline CFO & Operating cash flow \\
EARN & Net income before the deduction of costs \\
SFCF & Surplus free cash flow \\
CG & Corporate governance \\
Size & Firm size (natural logarithm of total assets) \\
DEBT & Long-term debt to total assets ratio \\
LOSS & A dummy variable taking the value of 1 if companies sustaining a loss and 0 otherwise \\
\hline 4.3 Statistical Population and Sample Selection
\end{tabular}

The research statistical population consists of all the companies listed in Tehran Stock Exchange. In this study, a sample of companies listed in Tehran Stock Exchange is examined during a 5-year period including the financial statements of 2010 to 2014 . The statistical sample has been selected through systematic removal method and companies which met all the following conditions have chosen as the statistical sample:

Table 2. Definition of Variables

\begin{tabular}{lc}
\hline \multicolumn{1}{c}{ Criteria for selection } & Number of companies \\
\hline All companies & 567 \\
They should not be among holding and investment companies. & 478 \\
Banks are excluded due to the special nature of their activities. & 385 \\
They should not have a change in the fiscal year or a stop in the ir & 266 \\
operations during the period under study. & 221 \\
Their required information should be available for conducting the & 184 \\
research. & 109 \\
The end of their fiscal year should be on March 19 (Esfand 29). & \\
They should have entered the stock exchange before the year 2008. &
\end{tabular}

\section{Empirical Results and Anal ysis}

\subsection{Descriptive Statistics}

Table 3 is the summary of descriptive statistics of the 545 observations

Table 3. Summary of Descriptive Statistics

\begin{tabular}{|c|c|c|c|c|c|c|c|}
\hline Variable & Signs & $\begin{array}{l}\text { Number } \\
\text { observations }\end{array}$ & Mean & Median & $\begin{array}{l}\text { Standard } \\
\text { deviation }\end{array}$ & Maximum & Minimum \\
\hline \begin{tabular}{lr} 
Earnings & \multicolumn{2}{c}{ predictability } \\
(future & operating cash \\
flow) &
\end{tabular} & $\mathrm{CFO}$ & 545 & 0.198 & 0.156 & 0.320 & 0.814 & -0.189 \\
\hline Firm size & SIZE & 545 & 5.381 & 5.452 & 0.739 & 7.233 & 3.368 \\
\hline Surplus free cash flow & SFCF & 545 & 0.185 & 0 & 0.720 & 1 & 0 \\
\hline \multicolumn{8}{|l|}{ Corporate governance } \\
\hline $\begin{array}{ll}\begin{array}{l}\text { Proportionate } \\
\text { directors }\end{array} & \text { outside } \\
\end{array}$ & BDIND & 545 & 0.716 & 0.67 & 0.360 & 0.79 & 0.19 \\
\hline Board size & BDSIZE & 545 & 4.988 & 4 & 0.398 & 7 & 4 \\
\hline Managerial owners & MOWN & 545 & 0.750 & 0.80 & 0.336 & 0.961 & 0.433 \\
\hline Institutional owners & IOWN & 545 & 0.293 & 0.244 & 0.436 & 0.891 & 0.080 \\
\hline
\end{tabular}

To select one of the methods of panel data or integrated data, F-Limer statistics is used. In other words, F-Limer test statistic determines whether or not there is a separate intercept for each of the companies. In F-Limer test, the null hypothesis indicates the similarity of intercepts (integrated data) and the opposite hypothesis suggests the dissimilarity of intercepts (panel data). Thus, in case of rejecting the null hypothesis, panel data method is accepted. 
Table 4. F-Limer test

\begin{tabular}{lccc}
\hline Effects Test & Statistic & d.f & Prob \\
\hline Cross- section F & 5.561 & $(88.779)$ & 0.000 \\
\hline Cross- section Chi- square & 426.591 & 88 & 0.000 \\
\hline
\end{tabular}

Given the results of the table 4 , the probability value of $\mathrm{F}$ statistic is equal to 0.0000 . So, the null hypothesis is rejected and panel data is considered to be appropriate.

If the null hypothesis is rejected after F-Limer test, this question arises as to in the form of which method (fixed effects or random effects) the relationship can be investigated. Hausman test clarifies this issue. The null hypothesis (random effects method) in this test means that there is no relationship between the error term related to the intercept and explanatory variables and they are independent of each other whereas the opposite hypothesis (fixed effects method) means that there is a correlation between the intended error term and explanatory variable. In case of rejecting the null hypothesis, fixed effects method is used. Otherwise, random effects method is applied.

Table 4. Hausman test

\begin{tabular}{cccc}
\hline Test Summary & Chi-Sq. Statistic & Chi-Sq. d.f & Prob \\
\hline Cross- section F & 36.939 & 7 & 0.000 \\
\hline
\end{tabular}

With regard to the results of the table above, the null hypothesis (random effects method) is rejected at the confidence level of 95 and regression will be estimated through fixed effects method.

Table 4. Estimation of model 1

\begin{tabular}{|c|c|c|c|c|c|}
\hline Variable & \multicolumn{2}{|l|}{ Coefficient } & Std. Error & t-Statistic & Prob. \\
\hline$\beta_{0}$ & \multicolumn{2}{|l|}{-0.033} & 0.007 & -4.414 & 0.000 \\
\hline EARN & \multicolumn{2}{|l|}{0.010} & 0.008 & 1.252 & 0.220 \\
\hline EARN*SFCF & \multicolumn{2}{|l|}{-0.002} & 0.001 & -2.123 & 0.034 \\
\hline EARN*CG & \multicolumn{2}{|l|}{0.001} & 0.000 & 2.287 & 0.028 \\
\hline EARN*SIZE & \multicolumn{2}{|l|}{0.002} & 0.001 & 1.785 & 0.044 \\
\hline EARN*DEBT & \multicolumn{2}{|l|}{-6.960} & 9.590 & -0.726 & 0.468 \\
\hline EARN*LOSS & \multicolumn{2}{|l|}{-1.150} & 1.430 & -0.798 & 0.424 \\
\hline YR & \multicolumn{2}{|l|}{-4.200} & 2.220 & -1.894 & 0.051 \\
\hline & R-squared & 0.200 & \multicolumn{2}{|c|}{ Mean dependent var } & 0.018 \\
\hline & Adjusted R-squared & 0.103 & \multicolumn{2}{|c|}{ S.D. dependent var } & 0.374 \\
\hline & S.E. of regression & 0.354 & \multicolumn{2}{|c|}{ Sum squared resid } & 98.020 \\
\hline & \multirow{2}{*}{$\begin{array}{c}\text { F-statistic } \\
\text { Prob(F-statistic) }\end{array}$} & 2.058 & \multicolumn{2}{|c|}{ Durbin-Watson stat } & 1.965 \\
\hline & & 0.000 & & & \\
\hline
\end{tabular}

According to model 1 whose information has been provided in Table 4 and with regard to the significance level obtained, there is a statistically significant relationship between earnings predictability and interactive relationship of surplus free cash flow. The amount of Student's t statistic obtained for this relationship is equal to 2.1233 and the relationship is inverse. Durbin-Watson statistic is 1.96 which indicates the absence of autocorrelation. Considering the probability of $\mathrm{F}$ statistic, the total regression model is also significant at the confidence level of 95 . Thus, the first research hypothesis cannot be rejected at the confidence level of 95 .

\subsection{Second Hypothesis Testing}

Considering the results of the table 5 , the probability value of $\mathrm{F}$ statistic is equal to 0.0000 . Hence, the null hypothesis is rejected and panel data is identified to be appropriate.

Table 5. F-Limer test

\begin{tabular}{lccl}
\hline Effects Test & Statistic & d.f & Prob \\
\hline Cross- section F & 5.756 & $(88,779)$ & 0.000 \\
\hline Cross- section Chi- square & 438.319 & 88 & 0.000 \\
\hline
\end{tabular}

To determine the preferred model from among fixed and random effects models, Hausman test is used which will be provided in the following.

Table 6. Hausman test

\begin{tabular}{cccc}
\hline Test Summary & Chi-Sq. Statistic & Chi-Sq. d.f & Prob \\
\hline Cross- section F & 14.592 & 7 & 0.032 \\
\hline
\end{tabular}

With regard to the results of the table above, the null hypothesis (random effects method) is rejected at the confidence level of 95 and regression will be estimated through fixed effects method. 
Table 7. Estimation of model 2

\begin{tabular}{ccccc}
\hline Variable & Coefficient & Std. Error & t-Statistic & Prob. \\
\hline$\beta_{0}$ & 16.203 & 0.400 & 40.496 & 0.000 \\
EARN & 0.867 & 0.657 & 1.319 & 0.187 \\
EARN*SFCF & -0.002 & 0.004 & -0.542 & 0.587 \\
EARN*CG & 0.110 & 0.047 & 2.347 & 0.019 \\
EARN*CG*SFCF & 0.673 & 0.094 & 7.122 & 0.000 \\
EARN*SIZE & 0.122 & 0.133 & 0.919 & 0.358 \\
EARN*DEBT & -0.003 & & -2.219 & 0.026 \\
EARN*LOSS & -0.002 & & -1.239 & 0.215 \\
YR & -4.348 & & -1.6001 & 0.102 \\
\hline & R-squared & 0.406 & Mean dependent var & 28.088 \\
& Adjusted R-squared & 0.334 & S.D. dependent var & 43.701 \\
& S.E. of regression & 36.795 & Sum squared resid & 1054714. \\
& F-statistic & 5.619 & Durbin-Watson stat & 1.710
\end{tabular}

Based on model 2 whose information has been provided in Table 7 and with regard to the significance level obtained for the mediating role of good corporate mechanisms in the relationship between surplus free cash flow and earnings predictability, it can be argued that good corporate mechanisms have a positive role in the relationship between surplus free cash flow and earnings predictability. The amount of Student's $t$ statistic obtained for this mediating role is equal to 7.1225 and type of mediation is positive, which shows that good corporate mechanisms enhance the relationship between surplus free cash flow and earnings predictability. Durbin-Watson statistic is 1.71 which suggests the absence of autocorrelation. Given the probability of F statistic, the total regression model is also significant at the confidence level of 95 . Therefore, the second research hypothesis cannot be rejected at the confidence level of 95 .

\subsection{Third Hypothesis Testing}

Since the aim is to compare small and large companies, to test the third hypothesis, model 2 (second hypothesis model) has been applied so that this model was tested once for small companies and once for large companies.

Table 8. Estimation of model 2 for large companies

\begin{tabular}{|c|c|c|c|c|c|}
\hline Variable & Coefficient & & Std. Error & $\mathrm{t}$-Statistic & Prob. \\
\hline$\beta_{0}$ & 0.063 & & 0.002 & 30.952 & 0.000 \\
\hline EARN & 4.700 & & 7.120 & 0.660 & 0.511 \\
\hline EARN*SFCF & -1.860 & & 4.690 & -0.397 & 0.692 \\
\hline EARN*CG & 0.001 & & 0.000 & 4.055 & 0.000 \\
\hline EARN*CG*SFCF & 0.002 & & 8.650 & 29.228 & 0.000 \\
\hline EARN*SIZE & 1.601 & & 4.141 & 3.872 & 0.000 \\
\hline EARN*DEBT & -2.641 & & 6.331 & -0.416 & 0.678 \\
\hline EARN*LOSS & -2.530 & & 8.540 & -0.295 & 0.768 \\
\hline YR & -3.310 & & 4.220 & -0.784 & 0.435 \\
\hline & R-squared & 0.497 & \multirow{5}{*}{\multicolumn{2}{|c|}{$\begin{array}{l}\text { Mean dependent var } \\
\text { S.D. dependent var } \\
\text { Sum squared resid } \\
\text { Durbin-Watson stat }\end{array}$}} & 2134.035 \\
\hline & Adjusted R-squared & 0.484 & & & 166134.7 \\
\hline & S.E. of regression & 119281.0 & & & 7.140 \\
\hline & F-statistic & 38.234 & & & 2.432 \\
\hline & Prob(F-statistic) & 0.000 & & & \\
\hline
\end{tabular}

According to model 2 estimated for large companies whose information has been presented in Table 8 and with regard to the significance level obtained for the mediating role of good corporate mechanisms in the relationship between surplus free cash flow and earnings predictability in large companies, the amount of Student's t statistic obtained for this mediating role is equal to 29.22855 and type of mediation is positive, which shows that good corporate mechanisms in large companies enhance the relationship between surplus free cash flow and earnings predictability. Durbin-Watson statistic is 2.43 which suggests the absence of autocorrelation. Considering the probability of $\mathrm{F}$ statistic, the total regression model is also significant at the confidence level of 95. 
Table 9. Estimation of model 2 for small companies

\begin{tabular}{ccccc}
\hline Variable & Coefficient & Std. Error & t-Statistic & Prob. \\
\hline$\beta_{0}$ & -2.001 & 1.311 & -1.520 & 0.132 \\
EARN & 1.511 & 2.291 & 0.658 & 0.512 \\
EARN*SFCF & -8.689 & 6.114 & -1.128 & 0.262 \\
EARN*CG & 0.083 & 0.0254 & 2.294 & 0.001 \\
EARN*CG*SFCF & 2.950 & 4.500 & 6.556 & 0.000 \\
EARN*SIZE & 3.531 & 5.711 & 0.617 & 0.539 \\
EARN*DEBT & -3.400 & & -0.611 & 0.542 \\
EARN*LOSS & -6.481 & & -0.239 & 0.811 \\
YR & -3.501 & & -0.570 & 0.591 \\
\hline & R-squared & 0.294 & Mean dependent var & 10460.85 \\
& Adjusted R-squared & 0.278 & S.D. dependent var & 64360.84 \\
& S.E. of regression & 55041.18 & Sum squared resid & 1.271 \\
& F-statistic & 19.436 & Durbin-Watson stat & 1.698
\end{tabular}

Based on model 2 estimated for small companies whose information has been provided in Table 9 and with regard to the significance level obtained for the mediating role of good corporate mechanisms in the relationship between surplus free cash flow and earnings predictability in small companies, the amount of Student's t statistic obtained for this mediating role is equal to 6.5569 and type of mediation is positive, which shows that good corporate mechanisms in small companies enhance the relationship between surplus free cash flow and earnings predictability. Durbin-Watson statistic is 1.69 which indicates the absence of autocorrelation. Considering the probability of $\mathrm{F}$ statistic, the total regression model is also significant at the confidence level of 95.

By summing up what has been mentioned above, it can be argued that good corporate mechanisms can enhance the relationship between surplus free cash flow and earnings predictability in both small and large companies. But with regard to the amount of Student's t obtained and comparing it in the above two models, it can be stated that the positive impact of governance mechanisms on the relationship between surplus free cash flow and earnings predictability is more prominent in larger companies. Thus, the third research hypothesis is also confirmed.

\section{Discussion and Conclusion}

Earnings forecast by the management is considered among the most important information resources of investors and other parties because in capital markets, there are declarations and notifications that are published by the companies in connection with announcing the expected earnings per share. If earnings forecasts by the management enjoy the necessary precision, they can lead to the improvement of the decision-making process of users of accounting reports. Karamanou (2005) believes that corporate governance mechanisms affect the quality of information disclosed by the companies, including the information associated with earnings forecast. Besides, Norvative et al. (2010) state that corporate governance is a factor that can improve the quality of information provided by the management. In line with the results of the present study, Sabz Alipour et al. (2012) came to the same conclusions. They found that there is a significant positive relationship only between the percentage of non-executive board members and earnings forecast accuracy and no significant relationship exists between other components of corporate governance and earnings forecast accuracy. In this regard, Rezaei and Teimouri (2012) examined the interactive relationships between free cash flow risk, corporate governance structure and debt policy of companies. The results demonstrate that there is no significant relationship between the variables of corporate governance and free cash flow risk. But there is a significant negative relationship between board members independence and debt with free cash flow risk. In line with the research results, Adinehzadeh and Jaffar (2013) investigated the relationship between corporate governance and free cash flow of 211 companies listed in Malaysia Stock Exchange. The results showed a significant positive relationship between independence degree, size and appropriateness of the audit committee with the level of free cash flow.

The researcher's analysis regarding the existence of the moderating role of some corporate governance variables indicates that corporate governance rules in Tehran Stock Exchange have managed to moderate and neutralize some of the factors affecting the negative relationship between surplus free cash flow and earnings predictability. Considering the results obtained from the study, among these cases is the impact of corporate governance on this issue. The research results are consistent with the studies conducted by Haqiqat and Asadollahi (2011), Sabz Alipour et al. (2012) Resaeiyan et al. (2010), John et al. (2012) and Dehmari and Coesmaeil (2014).

Given the results of this study and to promote the efficiency of Tehran Stock Exchange, the following suggestions are provided: 
Some actions have been taken in Iran concerning the corporate governance system. But the expansion of activities related to the establishment of a proper corporate governance system is essential. Proper establishment of these structures is a basic measure for optimum use of resources, promotion of accountability, transparency, conformity to justice and respect for the rights of all stakeholders of the company. With regard to the global wave of privatization and necessity of implementing the Article 44 of the Constitution for the economic development of the country based on social justice and poverty alleviation, formulation and application of the principles of corporate governance system in our country are important and inevitable for the development of capital market.

Considering the results of this study and to promote the better management of stock exchange companies, the following recommendations are presented:

According to the research results, surplus free cash flow has a negative impact on earnings predictability and with regard to the obtained results, the prominent effect of firm size on the negative relationship between surplus free cash flow and earnings predictability has been properly shown. Thus, free cash flow management particularly in large companies has great importance and priority.

\section{References}

Aqaei, M., \& Chalaki, P. (2009). Investigating the relationship between corporate governance features and earnings management in companies listed in Tehran Stock Exchange. Journal of Accounting Research, 1(4), 24-36.

Haqiqat, H., \& Asadollahi, A. (2011). Usefulness of accounting estimates in earnings forecast and future cash flows. Empirical Research in Financial Accounting, 1(2), 29-45.

Haqiqat, H., \& Mo'tamed, M. (2011). Examining the relationship between volatility and earnings predictability. Shiraz University Journal of Accounting Developments, 3(2), 65-87.

Hassas, Y. Y., \& Baghoumiyan, R. (2006). Role of the Board of Directors in corporate governance. Accountant Monthly Magazine, 173, 30.

Izadiniya, N., \& Resaeiyan, A. (2010). Corporate governance monitoring tools, level of cash holdings and performance of the companies listed in Tehran Stock Exchange. Journal of Research and Economic Policies, $18(55), 141-154$.

Mashayekh, S., \& Esmaeili, M. (2007). Examining the relationship between earnings quality and some aspects of governance principles in the companies listed in Tehran Stock Exchange. Accounting and Auditing Studies, 45.

Ola, M., Qaemi Asl, M., Amin Zadegan, S., \& Azimi, A. (2014). Analyzing the relationship between corporate governance and economic added value in Tehran Stock Exchange. Scientific Research Journal of Management Accounting, 7(21), 59-70.

Resaeiyan, A., Rahimi, F., \& Hanjari, S. (2010). The impact of intra-organizational monitoring mechanisms of corporate governance on the level of cash holdings in Tehran Stock Exchange. Journal of Financial Accounting Research, 2(4), 125-144.

Sabz Alipour, F., Qeitasi, R., \& Rahmati, A. (2012). Evaluating the relationship between corporate governance mechanisms and earnings forecast accuracy. Journal of Financial Accounting Research, 4(2), 123-140.

Setayesh, M., \& Kargar, F. J. M. (2011). Investigating the influence of product market competition on capital structure. Quarterly Journal of Accounting Empirical Research, 1(1).

Vakili-fard, H., \& Bavandpour, L. (2010). The effect of corporate governance on the performance of the companies listed in Tehran Stock Exchange. Journal of Financial Studies, 8, 119-140.

\section{Copyrights}

Copyright for this article is retained by the author(s), with first publication rights granted to the journal.

This is an open-access article distributed under the terms and conditions of the Creative Commons Attribution license (http://creativecommons.org/licenses/by/4.0/). 